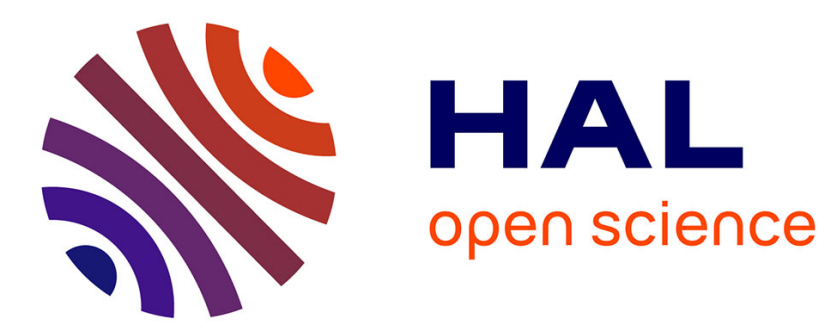

\title{
Physico-Chemical Study of Barium (II) Dipivaloylmethanate Nature
}

\author{
N. Fedotova, I. Igumenov, V. Mamatyuk, G. Sidorenko
}

\section{To cite this version:}

N. Fedotova, I. Igumenov, V. Mamatyuk, G. Sidorenko. Physico-Chemical Study of Barium (II) Dipivaloylmethanate Nature. Journal de Physique IV Proceedings, 1995, 05 (C5), pp.C5-431-C5-438. 10.1051/jphyscol:1995550 . jpa-00253912

\section{HAL Id: jpa-00253912 https://hal.science/jpa-00253912}

Submitted on 1 Jan 1995

HAL is a multi-disciplinary open access archive for the deposit and dissemination of scientific research documents, whether they are published or not. The documents may come from teaching and research institutions in France or abroad, or from public or private research centers.
L'archive ouverte pluridisciplinaire HAL, est destinée au dépôt et à la diffusion de documents scientifiques de niveau recherche, publiés ou non, émanant des établissements d'enseignement et de recherche français ou étrangers, des laboratoires publics ou privés. 


\title{
Physico-Chemical Study of Barium (II) Dipivaloylmethanate Nature
}

\author{
N.E. Fedotova, I.K. Igumenov, V.I. Mamatyuk and G.V. Sidorenko \\ Institute of Inorganic Chemistry, Lavrentieva 3, Novosibirsk 630090, Russia
}

\begin{abstract}
A physico-chemical research of bis-(dipivaloylmethanato)barium(II) (Ba(thd) 2 ) has been carricd out from the point of its use in CVD processes as a precursor (thermal stability, immunity to external effects and etc.). The optimal conditions for synthesis, purification and storage have been found. It has been shown. that the sublimated product presents a mixture of several modifications with the main phase of a composition $\mathrm{Ba}_{4}$ (thd) 8 . At a lowered pressure the sublimated product is preserved without decomposition for a long time. In the air it is a monomer of a composition $\mathrm{Ba(thd})_{2} * 2 \mathrm{H}_{2} \mathrm{O}$, decomposing in the course of time with forming a free ligand or a diketone $\left(\mathrm{C}_{8} \mathrm{H}_{2} \mathrm{O}_{2}\right)$ depending on the way of purification of the initial compound.
\end{abstract}

\section{INTRODUCTION}

The synthesis of the $\mathrm{HTSC}_{\mathrm{YBa}} \mathrm{Cu}_{3} \mathrm{O}_{7-\mathrm{x}}$ films by the chemical vapour deposition (CVD) is based on the possibility to obtain the $\mathrm{Y}_{2} \mathrm{O}_{3}, \mathrm{BaO}$ and $\mathrm{CuO}$ films from volatile chelates of these metals [1-7], As the dipivaloylmethanates of $\mathrm{Y}$ (III), Ba(II) and $\mathrm{Cu}(\mathrm{II})$ have a substantial vapour pressure already at $150-250^{\circ} \mathrm{C}$ [1], it is these complexes that are used as precursors in CVD processes. The main problem, arising at the preparation of oxide barium films, is a low reproducibility of the experiments Peculiar of the complexes of the alkaline-earth metals is the ion nature of the metal-ligand coordination bond, as a consequence, the latter are highly susceptible to polymerization [8-15]. In the case of $\mathrm{Ba}$ (thd $)_{2}$ the propensity to polymerization makes conditions for existence of this complex in several modifications of similar, or close-to-similar compositions [11-16], which in its turn influences on stability of this compound to external effects. Traditionally the introduction of additional donor molecules, such as the $\mathrm{H}_{2} \mathrm{O}, \mathrm{CH}_{3} \mathrm{OH}, 1,10$-phenantroline (Phen) and etc. [12], as well as the use of fluorocontaning ligands $[3,4,6]$ leads to the formation of more stable monomeric compounds. But, firstly, for barium complexes the introduction of $\mathrm{H}_{2} \mathrm{O}$ results in oligomeric complexes, such as $\left[\mathrm{Ba}_{5}\right.$ (thd), $\left.\mathrm{OH}\left(\mathrm{H}_{2} \mathrm{O}\right)_{3}\right][\mathrm{Il}]$, [ $\left[\mathrm{Ba}_{6}(\mathrm{thd})_{12}\left(\mathrm{H}_{2} \mathrm{O}\right)_{13}\right]$ [17], secondly, only few mixed-ligand complexes can be transferred into the gas phase with preserving the structural unit and, thirdly, as is shown in refs. $[3,6]$, the vapour mixture of three precursors is accompanied by undesirable side chemical reactions in the gas phase. In order to simplify the HTSC film growing process it is expedient to use complexes with the same ligand. As far as Hthd is the most widely used ligand, it seems impossible, at least for the time being, to refuse the use barium (II) dipivaloylmethanate as the precursor in the CVD processes. The wide circle of papers devoted to the synthesis and research of physico-chemical properties of $B a(1 h d) 2$ and its derivatives contains a number of inconsistent data $[7.11-20]$. On the one hand. the structures of two modifications of water-free Batthd s $1: 2-15 /$ and mumber of mixedligand complexes [1], 12. 16, 17] isolated at recrystallization from domor solvents have been 
established. On the other hand, there are essential discrepancies in the melting temperatures (142$172^{\circ} \mathrm{C}, 185-192^{\circ} \mathrm{C}[7,8], 160-165^{\circ} \mathrm{C}, 158-165^{\circ} \mathrm{C}[16]$ depending on the method of synthesis) and also in the information on the capability of $\mathrm{Ba}$ (thd) $)_{2}$ to sublimate (Ba(thd) 2 is described as a nonvolatile product $[20] ; \mathrm{T}_{\text {sub. }}=220-240^{\circ} \mathrm{C}[1-3,5,6], \mathrm{T}_{\text {sub }}=280^{\circ} \mathrm{C}[21], \mathrm{T}_{\text {sub }}=190-240^{\circ} \mathrm{C}$ [22]). Having analyzed the data from publications and based on the results of alkaline-earth metal $\beta$ diketonates studies carried out at our laboratory [23], we have came to a conclusion that the reason of the discrepancies and insufficient reproducibility of the results in the experiments with $\mathrm{Ba}(\mathrm{thd})_{2}$ is a probable existence of the complex several modifications, the formation of mixed-ligand complexes. the hydrolysis of the compounds and sensitivity of $\mathrm{Ba}(\text { thd })_{2}$ to external effects.

To reveal the chemical nature and properties of $\mathrm{Ba}(\text { thd })_{2}$ as the precursor depending on the synthesis, purification and storage conditions, we have carried out NMR-, IR-, and Ramanspectroscopy, chromatography, thermoanalytical and X-ray diffraction studies of the complex.

\section{EXPERIMENTAL}

General Nomenclature: 2,2,6,6-tetramethylheptane-3,5-dione (dipivaloylmethane, Hthd)

\subsection{Synthesis of $\mathrm{Ba}(\text { thd })_{2} * 2 \mathrm{H}_{2} \mathrm{O}$}

$\mathrm{Ba}$ (thd) $)_{2} * 2 \mathrm{H}_{2} \mathrm{O}$ was prepared when reacting a freshly prepared barium hydroxide (aqueous solution) and Hthd (alcohol solution) (4:1). The water-alcohol solution was stirred without heating for about $30 \mathrm{~min}$. Ba(thd $)_{2} * 2 \mathrm{H}_{2} \mathrm{O}$ was precipitated by a five-fold amount of water and collected by filtration on a glass filter. To optimize the synthesis conditions, we have found a relationship between the yield of $\mathrm{Ba}$ (thd $)_{2} * \mathrm{xH}_{2} \mathrm{O}$, the amount of barium hydroxide and the temperature of the reaction mixture. The yield of $\mathrm{Ba}$ (thd $)_{2}$ was shown to be maximal at a 4 -fold excess of barium hydroxide, whereas a heating of the reaction mixture to $80^{\circ} \mathrm{C}$ gives rise to the formation of considerable amounts of a barium carbonate.

\subsection{Recrystallization}

The crude product was solved in a minimal volume of alcohol, filtered and precipitated by adding a 10 -fold excess of water with stirring. The precipitate was collected on a glass filter and then dried. The results of elemental analysis correspond to a dihydrate of barium dipivaloylmethanate $\mathrm{Ba}$ (thd) $2 * 2 \mathrm{H}_{2} \mathrm{O}$ :

found: C $48.81 \%, \mathrm{H} 7.60 \%$; calculated: C $48.95 \%, \mathrm{H} 7.79 \%$.

To find the Hthd-ligand content in the recrystallized product, a gas-liquid chromatographic technique was applied. (A weight of the product was decomposed by $20 \% \mathrm{H}_{2} \mathrm{SO}_{4}$ and the released $\mathrm{Hthd}$ was extracted with isooctane. Hexachloroethane served as a standard and 19\% dinonylphthalate on dinochrome II served as a stationary phase). The Hthd-ligand content in the recrystallized and airdried samples corresponds to that in a dihydrate $\mathrm{Ba}(\text { thd })_{2} * 2 \mathrm{H}_{2} \mathrm{O}$. The quantities are as follows: $67.7 \%$ (found) and $69.7 \%$ (calculated) for $\mathrm{Ba}(\text { thd })_{2} * 2 \mathrm{H}_{2} \mathrm{O}$.

\subsection{Sublimation}

$\mathrm{Ba}(\text { thd })_{2} * 2 \mathrm{H}_{2} \mathrm{O}$ was sublimated in a horizontal gradient furnace in special ampoules. The design of the ampoule allows the precursor to be sublimated twice. The compound was sublimated at $P=3-$ $5 * 10^{-2}$ Torr and $\mathrm{T}=210-230^{\circ} \mathrm{C}$. After the sublimation was finished, a cooled ampoule was 
unsoldered at $\mathrm{P}=5 * 10^{-2}$ Torr

Chromatographic studies of sublimated samples have confirmed that it is anhydrous. The found amount of Hthd corresponds to $\mathrm{Ba}(\text { thd })_{2}$. The found and calculated amounts are $73.1 \%$ and $72.7 \%$, respectively (for $\mathrm{Ba}$ (thd) 2 ).

\subsection{The procedure of handling the sublimated $\mathrm{Ba}(\text { thd })_{2}$}

The work with sublimated $\mathrm{Ba}$ (thd) $)_{2}$ : unsoldering of the ampoule, preparation of solution for the NMR experiments, gas-liquid chromatographic experiments were performed in a dry chamber. $\mathrm{P}_{2} \mathrm{O}_{5}$ and $\mathrm{NaOH}$ served as dryers and absorbers of $\mathrm{CO}_{2}$, respectively; the chamber was cleaned with dry argon for 24 hours before the work started. The residual pressure of water vapour was estimated to be $2 * 10^{-5}$ Torr

\section{RESULTS AND DISCUSSION}

\subsection{Definition of forms of barium dipivaloylmethanate}

It is worth mentioning that the information derived by means of this or that physico-chemical research technique is not sufficient to identify an exact composition of the complex. Only a comprehensive study has enabled definite conclusions on the properties and composition of the complex to be drawn

\section{I.I Infrared spectroscopic analysis}

The spectrum of recrystallized and air-dried $\mathrm{Ba}(\mathrm{thd}))_{2} * 2 \mathrm{H}_{2} \mathrm{O}$ is in accord with the data of [20, 22] The lines of valent vibrations $\left(\mathrm{cm}^{-1}\right)$ lie in the regions usual for metal $\beta$-diketonates: $\mathrm{C}==\mathrm{O}(1590$, $1575,1560) ; \mathrm{C}==\mathrm{C}(1505,1450) ; \mathrm{C}-\mathrm{C}\left(\mathrm{CH}_{3}\right)_{3}(1415,1355) ; \mathrm{C}-\mathrm{CH}_{3}(1220,1240) ; \mathrm{M}==\mathrm{O}$ (475). The presence of bound water is confirmed by the absorption in the $3400 \mathrm{~cm}^{-1}$ range.

\subsubsection{Raman spectroscopic spectra}

In the spectrum of the recrystallized sample at a minimum intensity ( $\mathrm{I}, \mathrm{mV}$ ) of exciting radiation, among recorded are the following characteristic lines in the metal-ligand vibration region: 387 and $472 \mathrm{~cm}^{-1}$, and a weak structureless band $\left(500-580 \mathrm{~cm}^{-1}\right)$ wich frequency range correlates with vibrations of coordinated oxygen.

A comparison of the IR and Raman spectra with the results of alternative investigations $[12,16$, 17, 24] makes it possible to assume the formation of a mixture of water adducts under $\mathrm{Ba}$ (thd $)_{2} * 2 \mathrm{H}_{2} \mathrm{O}$ recrystallization from a water-alcohol solution. This accounts for both considerable errors in chemical analysis and a broadened interval of melting temperatures. The Raman spectrum of a sample, prepared in dry atmosphere, has the characteristic lines in the 387 and $472 \mathrm{~cm}^{-1}$ metalligand vibration ranges. 


\subsubsection{Thermal analysis}

TG, DTG and DTA curves of $\mathrm{Ba}$ (thd $)_{2} * 2 \mathrm{H}_{2} \mathrm{O}$ are shown in Fig. 1. We assign the endoeffect, minimal at $60^{\circ} \mathrm{C}$, to the dehydration of the complex (loss in the mass within $40-80^{\circ} \mathrm{C}$ : calculated $6.7 \%$, found $8.5 \%$ ). A gradual weight loss also occurs over this temperature, probably, due to a simultaneous process of Hthd withdrawal (minimum on DTG and DTA curves at $140^{\circ} \mathrm{C}$ ). Based on lliterary data [25] this process is attributable to hydrolysis: $\mathrm{Ba}(\text { thd })_{2}{ }^{*} 2 \mathrm{H}_{2} \mathrm{O} \rightarrow \mathrm{Ba}(\mathrm{OH})_{n}$ (thd $)_{\mathrm{n}}+(2-\mathrm{n}) \mathrm{Hthd}+\mathrm{H}_{2} \mathrm{O}$.

In [26] the endoeffect at $140^{\circ} \mathrm{C}$ is assigned to melting. At $175-180^{\circ} \mathrm{C}$ the endoeffect corresponds to melting of the complex, while an intense transition to the gas phase, accompaning by the decomposition, starts at $300^{\circ} \mathrm{C}$. The decrease in the sample weight amounts to $83 \%$, thereby corresponding to the evaporation of about $53 \%$ of $\mathrm{Ba}(\mathrm{thd})_{2}$ and does not contradict to the results of refs. $[8,26]$. If the complexes were decomposed entirely to $\mathrm{BaO}$ without sublimation the \% weight loss would be accounted for $72 \%$. According to the thermal analysis data of the double sublimated sample of anhydrous $\mathrm{Ba}$ (thd) $)_{2}$ is sufficiently thermal stable $\left(\mathrm{T}_{\text {sub }}=216^{\circ} \mathrm{C}, \mathrm{P}=3 * 10^{-3}\right.$ Torr $)$. The decrease in the sample weight amounts to $88 \%$, thereby corresponding to the evaporation of about $70 \%$ of $\mathrm{Ba}$ (thd) 2 (Fig. 1).

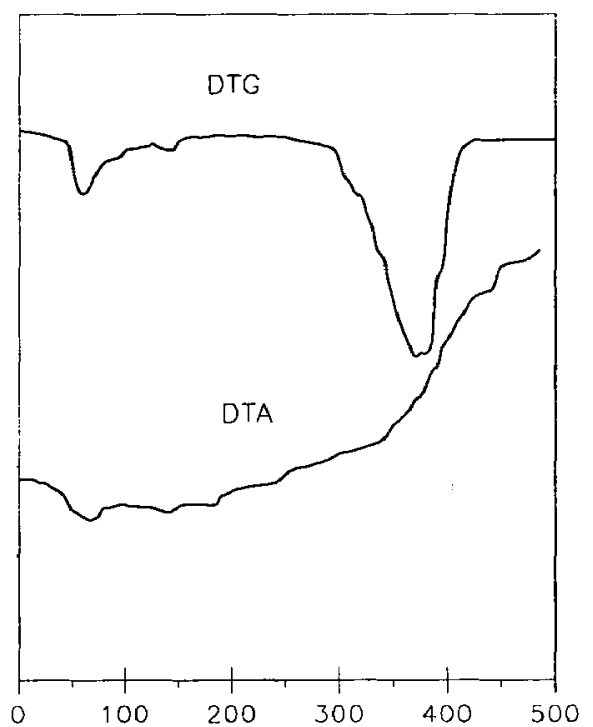

a) T. ${ }^{\circ} \mathrm{C}$

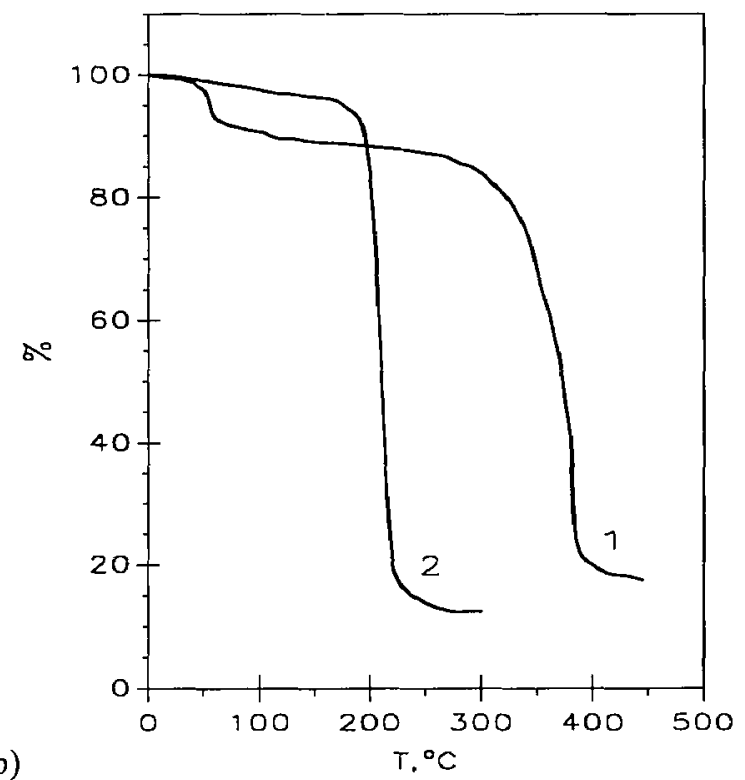

b) $T \cdot{ }^{\circ} \mathrm{C}$

Figure 1: a) Thermal curves at linear heating ( $\left.10^{\circ} / \mathrm{min}\right)$ of $\mathrm{Ba}(\mathrm{thd})_{2} * 2 \mathrm{H}_{2} \mathrm{O}$ in helium atmosphere; $b$ ) Thermograms of $\mathrm{Ba}(\text { thd })_{2} * 2 \mathrm{H}_{2} \mathrm{O}(1) ; \mathrm{Ba}(\text { thd })_{2}$ sublimated in vacuum at $\mathrm{P}=3 * 10^{-3}$ Torr (2).

\subsubsection{NMR spectra}

According to the NMR data (NMR spectra for $\mathrm{Ba}$ (thd) 2 were recorded on AC 200 Bruker spectrometer. Dry chloroform, $\mathrm{D}_{2}$-dichloromethane, carbon tetrachloride and $\mathrm{D}_{8}$-toluene were used as solvents. Chemical shifts are given in ppm relative to TMS.), the product, which was precipitated from the reaction mixture, is a dihydrate of barium dipivaloylmethanate. In the NMR spectra there are lines which are assigned to the complex, free ligand (as an impurity) and bound water. The complex (solvent $\mathrm{CD}_{2} \mathrm{Cl}_{2}, 8\left[\mathrm{CHDCl}_{2}=5.3 \mathrm{ppm}\right]$ ) is: $\mathrm{CH}_{3}-1.008, \mathrm{CH}-5.56$ and $\mathrm{H}_{2} \mathrm{O}-5.0 \mathrm{ppm}$. The fire ligand contains enol: $\mathrm{CH}_{3}-1.14, \mathrm{CH}-5.74, \mathrm{OH}-16.0 \mathrm{ppm}$ and ketone: $\mathrm{CH}_{2}-3.72 \mathrm{ppm}$ (Fig. 2). 
The mole share of the free ligand decreases in going from crud product to recrystallized sample.

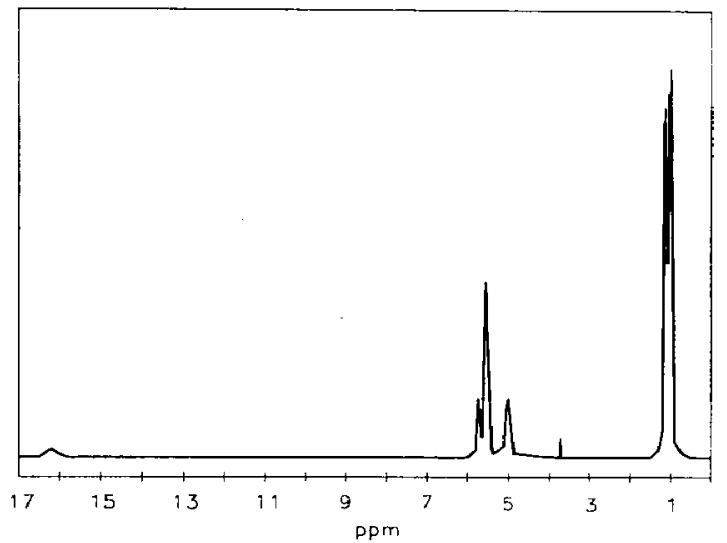

Figure 2: The PMR spectrum of crude product.

The NMR spectrum of ${ }^{13} \mathrm{C}$ shows the complex: $\mathrm{CH}_{3}-28.9,-\mathrm{C}-41.3, \mathrm{CH}-90.6$ and $\mathrm{C}=\mathrm{O}-199.7$ $\mathrm{ppm}$; the free ligand: there are bands of only $\mathrm{CH}_{3}$ - group at $27.7 \mathrm{ppm}$; the other signals are not seen because of a low signal-to-noise ratio (low concentration) (Fig. 3). The mole water-ligand ratio in the complex is about 1:1, which corresponds to a dihydrate. As it has been noted, the dissolution in some solvents contributes to the destruction of the complex accompanied by the formation of the barium carbonate. As the NMR data show, the complex can be regenerated from $\mathrm{CCl}_{4}, \mathrm{C}_{6} \mathrm{H}_{6}$ and $\mathrm{CHCl}_{3}$, but the amount of bound water approximately halves thus indicating $\mathrm{Ba}(\text { thd })_{2} * \mathrm{H}_{2} \mathrm{O}$. The extraction of the complex from heptane has failed. Only the signals of unidentified compounds have been found in the spectra of the samples extracted from the heptane.

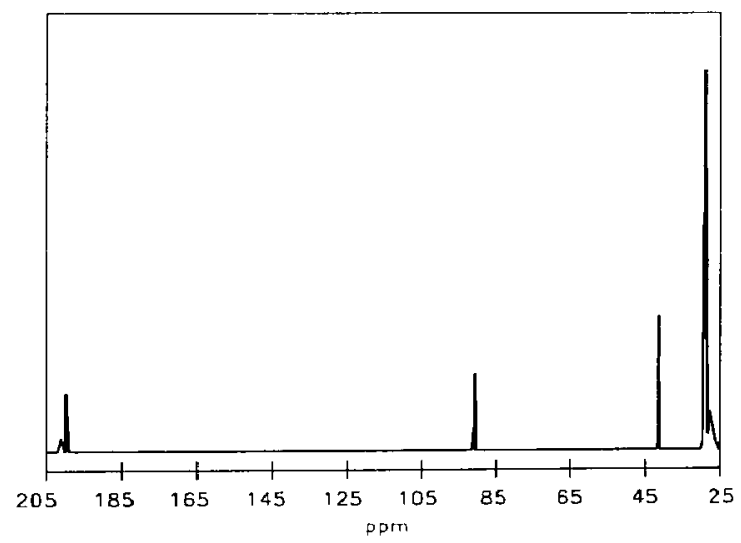

Figure 3: The NMR spectrum of crude product.

The studies performed on the sublimated samples have shown that the NMR spectra of the samples prepared in unpolar solvents $\left(\mathrm{CCl}_{4}\right.$, toluene) are much different from the NMR spectra of the initial complex (Fig. 4) $\left({ }^{1} \mathrm{H}\right.$ spectrum. solvent $\left.\mathrm{CCl}_{4}: \mathrm{CH}_{3}-1.20 .1 .28 ; \mathrm{CH}-5.72,5.80 \mathrm{ppm}\right)$. Passing from $\mathrm{CCl}_{4}$ to $\mathrm{CHCl}$, and also with the use of pyridine or water as donors the spectrum returns to the initial shape (Fig. 2). Such behaviour of the compound can be unambiguously interpreted as the 
polymerization-depolymerization effect. If one works with the sublimated sample in air, the NMR spectra show only $\mathrm{Ba}(\text { thd })_{2} * \mathrm{xH}_{2} \mathrm{O}$.

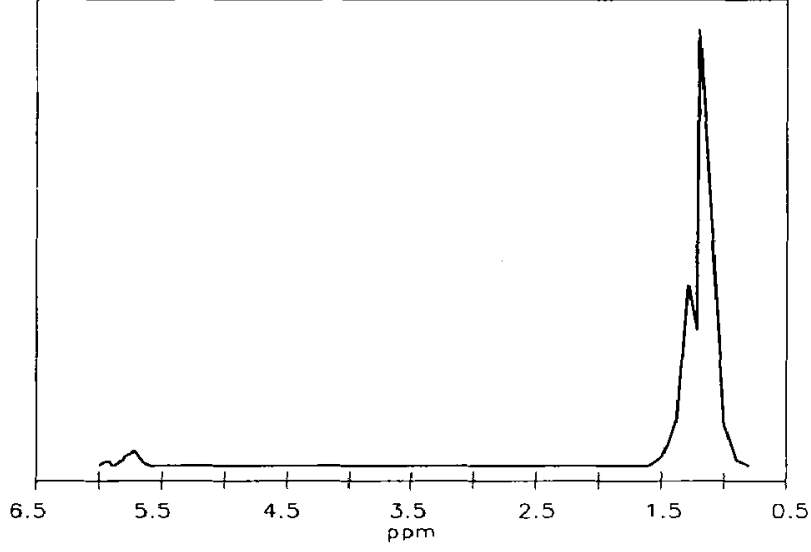

Figure 4: The PMR spectrum of sublimated $\mathrm{Ba}(\mathrm{thd})_{2}$.

The low-temperature NMR studies (Fig. 5) have not made it possible to identify the structure of the complex in a solution without ambiguity. Despite our precautions, we have not succeeded in obtaining a $\mathrm{Ba}$ (thd) $)_{2}$ solution in $\mathrm{D}_{8}$-toluene, not containing the traces of $\mathrm{H}_{2} \mathrm{O}$ and, therefore, some signals can be assigned to hydrated forms of $\mathrm{Ba}(\text { thd })_{2} * \mathrm{xH}_{2} \mathrm{O}$. A considerable complication of the NMR spectrum at decreased temperatures, in particular the signal broadening and splitting, indicates the existence of a number of chemical forms and/or nonequivalent sites of thd and also of a rapid exchange at a room temperature. A variety of lines within the $\mathrm{CH}$ and $\mathrm{CH}_{3}$ resonance is an attribute of the formation of coordinate polymers.

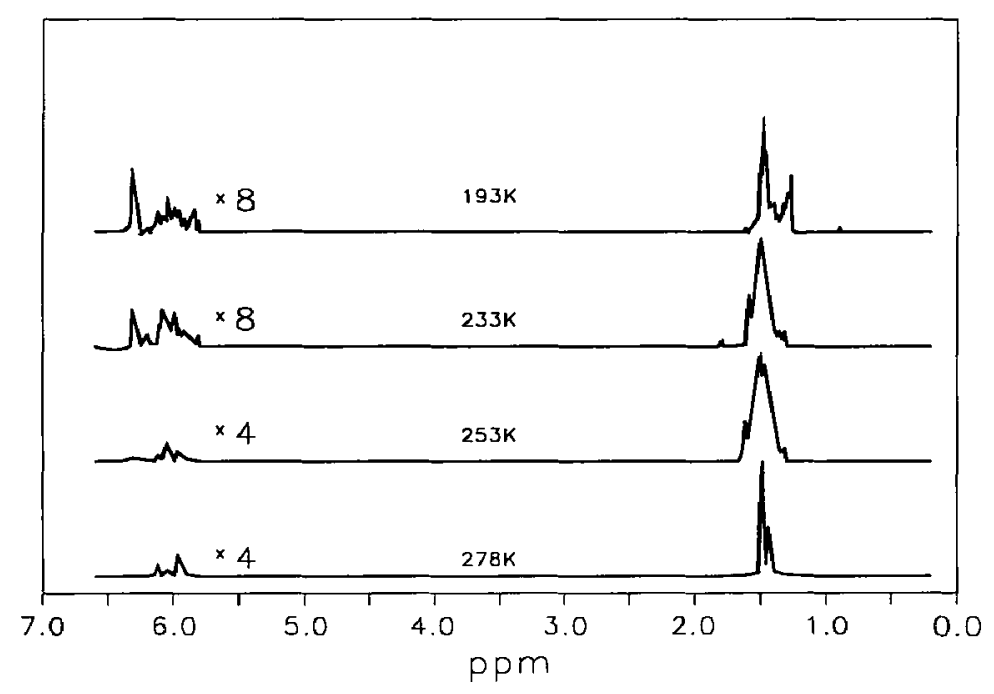

Figure 5: The PMR spectrum of sublimated $\mathrm{Ba}(\mathrm{thd})_{2}$ at different temperatures. 


\subsubsection{X-ray diffraction arialysis}

According to XRD data, the main phase of sublimated product is a rhombic modification of $\mathrm{Ba}_{4}(\mathrm{thd})_{8}$ [13]. Relative intensities of doped phase do not exceed 15-20\%. Measurements carried out in a twenty four hours have disclosed that the new phase arises. We suggest that it may be $\mathrm{Ba}(\text { thd })_{2} * \mathrm{xH}_{2} \mathrm{O}$. The following change of this phase was not detected.

On the basis of our investigation it may be concluded that the sublimation of a dihydrate of barium (II) dipivaloylmethanate results in the formation of an anhydrous complex with the $\left[\mathrm{Ba}(\mathrm{thd})_{2}\right]_{4}$ oligomer structure of several modifications. It is confirmed by literary data $[8-10,12,14,15,18]$ and the results of mass spectrometric studies of $\mathrm{Ba}(\mathrm{thd})_{2}$ in the gas phase carried out at our laboratory [27].

\subsection{Analysis of the decomposition products of $\mathrm{Ba}(\text { thd })_{2} * 2 \mathrm{H}_{2} \mathrm{O}$}

Analyzing the reasons of the irreproducibility of experiments in the case of Ba oxide films, we have paid attention to the fact that the outlook of the complex changes with time. It has turned out that depending on the storage conditions, the complex decomposes with the formation of either a free ligand or the lower diketone. For example, upon heating of sublimated $\mathrm{Ba}(\mathrm{thd})_{2}$ in the vacuum after its prolonged storage (in darkness, over a drier) a volatile crystalline substance was extracted. Using the NMR technique, it was identified as $\left(\mathrm{CH}_{3}\right)_{3} \mathrm{C}-\mathrm{CO}-\mathrm{CH}=\mathrm{CH}-\mathrm{CO}-\mathrm{C}\left(\mathrm{CH}_{3}\right)_{3}$. The $\mathrm{JHH}$ for $14.5 \mathrm{~Hz}$ double-bond protons (found from satellites of ${ }^{13} \mathrm{C}$ in the PMR spectrum) allows to identify it as a trans-product. In PMR spectra the shifts are $\left(\mathrm{CH}_{3}\right)_{3}-1.16$ and $\mathrm{CH}=7.42 \mathrm{ppm}$. In the spectrum of ${ }^{13} \mathrm{C}$ the shifts are as follows: $\mathrm{CH}_{3}-25.92,-\mathrm{C}-43.90, \mathrm{CH}=133.46$ and $\mathrm{C}=\mathrm{O} 205.2 \mathrm{ppm}$. The data are consistent with the results of the elemental analysis (found: $\% \mathrm{H} 10.15, \% \mathrm{C} 73.4, \% \mathrm{O} \quad 16.4$; calculated: \% $\mathrm{H} 10.26, \% \mathrm{C} 73.43, \% \mathrm{O} 16.30)$, infrared ( $\mathrm{CO}, \mathrm{cm}^{-1}: 1670 \mathrm{st}, 1650 \mathrm{~m}$ ) and Raman spectroscopic ( $\mathrm{VCO}, \mathrm{cm}^{-1}: 1699 \mathrm{~m} ; \mathrm{vCC}, \mathrm{cm}^{-1}: 1612 \mathrm{st}$ ) experiments. According to our assumption, the formation of this unsaturated diketone is caused by the condensation reaction between the probable products of oxidizing and hydrolytic splitting of a thd anion: trimethylpyroracemic aldehyde and pinakolone. After a three-month storage of the sublimated $\mathrm{Ba}(\mathrm{thd})_{2}$, in the NMR spectrum the unsaturated diketone mentioned above, free ligand, water and other unidentified products were found. Three months after the synthesis of the non sublimated $\mathrm{Ba}(\mathrm{thd})_{2} * 2 \mathrm{H}_{2} \mathrm{O}$, only a free ligand was recorded in the NMR spectrum of this compound, i.e. the complex is practically not found. The sublimated $\mathrm{Ba}_{4}$ (thd) 8 is conserved in vacuum-soldered ampoules for a long time without changes. Practically, there are no changes in the NMR spectra of $\mathrm{Ba}_{4}$ (thd) 8 after its 3 -month storage in a soldered ampoule. It is apparent that one of the factors responsible for the decomposition of the complex is its contact with $\mathrm{CO}_{2}$ or $\mathrm{O}_{2}$, because such precautions as darkness, low ambient temperature and drying have no noticeable effect on the behaviour of the substance. It is interesting to note that the diketone is formed upon storage of only a sublimated product.

\section{CONCLUSION}

The results of the present work show that the sublimated product presents a mixture of several modifications of composition $\mathrm{Ba}($ thd) 2 . The main phase of this mixture is $\mathrm{Ba} 4($ thd $) \mathrm{g}$ having a thombic modification. The sublimated product is stored at a lowered pressure for a long time without changes. In the air it is a dihydrate of barium (II) dipivaloylmethanate gradually decomposing.

Thus, when satisfying all the synthesis, purification and storage conditions (relationship between reagents, temperature condition, choice of solvents, etc.) it is possible to avoid the problems connected with specific peculiarities of Ba(thd) 2 and increase the stability of the (VD process results. Since the work with Ba(thd)2 is rather complicatod, a search for news. more stable Ba-containing conpounds suitable for obtainm g oxide coatings seems to be evidently important. 


\section{References}

[1] Tsuruoka T., Takahasyi H., Rawasaket R. et al., Appl. Phys. Lett. 54 (1989) 1808-1809.

[2] Yamand H., Masumoto H., Hirari N. et al., Appl. Phys. Lett. 53 (1988) 1548-1550.

[3] Bai G.R., Tao W., Wang R. et al., Appl. Phys. Lett. 55 (1989) 194-196.

[4] Zhao J., Marcy H.O., Tomge L.M. et al., Physica 159 (1989) 710-714.

[5] Kaneori K., Nobuyki S. and Katsuki M., J. Solid State Chem. 82 (1989) 103-108.

[6] Berry A.D., Gaskill D.K., Holm E.Y. et al., Appl. Phys. Lett. 52 (1988) 1743-1745.

[7] Holzsehuh H., Oehr C., Suhr H. and Weber A., Modern Physics Letters B 2 (1988) 1253-1257.

[8] Schwarberg J.E., Sievers R.E. and Moshier R.W., Anal Chem. 42 (1970) 1828-1830.

[9] Macdonald C.C. and Shannon J.S., Aust. J. Chem. 19 (1966) 1545-1566.

[10] Macklin J., Dubek G., Inorg. Nucl. Chem. Lett. 2 (1966) 403-407.

[11] Ling Huang, Turnipseed S.B., Haltiwanger C. et al., Inorg. Chem. 33 (1994) 798-803.

[12] Gleizes A., Sans-Lenain S. and Medus D. C.R., Acad. Sci. Paris 313, Serie II (1991) 761-766.

[13] Glaz A., Drozdov A.A. and Troyanov S.I., Koord. Khint. 20 (1994) 922-927 (in Russian).

[14] Drake S.R., Hursthouse M.B., Malik K.M A. and Otway D.J., J.Chem. Soc. Dalton Trans (1993) 2883-2890

[15] Drozdov A. A and Troyanov S. I, Polyhedrom 11 (1992) 2877-2882.

[16] Turnipseed S.B., Barkley R.M. and Sievers R.E., Inorg. Chem. 30 (1991) 1164-1 170

[17] Drozdov A A and Troyanov S.I. and Pisarevsky A.P., Polyhedron 13 (1994) 2459-2463.

[18] Belcher R., Granley C.R., Majer J.R. et al, Anal. Chim. Acta 60 (1972) 109-116.

[19] Hammond G.C., Nonhebel D.C. and Wu C.S, Inorg. Chem. 2 (1963) 73-76.

[20] Berg E.W.and Herrera N.M., Anal. Chim. Acta 60 (1972) 117-125.

[21] Devyatykh G.G., Gavrishchuk E.M., Gibin A.M. et al., Vysokochistye veshchestva, 6 (1990) $90-94$ (in Russian).

[22] Aoki S., Yamaguchi T., Sadakata N. and Kohno O., ASC'OO pp. 1-4.

[23] Morozova N.B., Zharkova G.I., Stabnikov P.A. et al., Synthesis and physico-chemical investigation of alkaline-earth metal $\beta$-diketonates (Izd. Sibirsk. Otd. Akad. Nauk SSSR, Inst. Neorg. Khim., Novosibirsk, 1989) 28 p. (in Russian).

[24] Drozdov A.A.and Troyanov S.I. and Pisarevsky A.P., Polyhedron 13 (1994) 1445-1451

[25] Kuzmina N.P., Zaitsev I.G., Tchechernikova M. V. at al., Zhurn. Inorg. Khim. 36 (1991) 2739-2744 (in Russian).

[26] Hamrima H., Ohishi H., Hanaoka K. et al., Jpn. Appl. Phys. 29 (1990) 1932-1938.

[27] Fedotova N.E., Bykov A.F. and Igumenov I.K., "Physico-chemical study of barium dipivaloylmethanate nature", Fizicheskiye metody v koordinatsionnoy khimii (Kishinev, 1990) pp. 234 (in Russian). 